\title{
MINING OF UNDERGROUND DEPOSITS IN DIFFICULT GEOLOGICAL CONDITIONS
}

Serhii Pysmennyi

Kryvyi Rih National University, Ph.D. (Engineering), Associate Professor, Ukraine

Kanay Rysbekov

Institute of Geology, Petroleum and Mining engineering Satbayev University, PhD (Engineering), Associate professor, Kazakhstan

\section{Serhii Chukharev}

National University of Water and Environmental Engineering (NUWEE), Ph.D. (Engineering), Associate Professor, Ukraine

\section{Branko Gluščević,}

University of Belgrade, faculty of Mining and Geology, $\mathrm{PhD}$ (Engineering), Associate Professor, Serbia

\begin{abstract}
The article studies stability of intervening pillars at underground selective mining of complex structured ore bodies of Kryvyi Rih iron ore basin applying open stope systems that will enable the increased useful mineral component content in the mined ore mass. When calculating an exposure span, the current methods of determining room system constructive elements do not consider dirt thickness. So, it is essential to develop methods of determining room system constructive elements for mining complex structured ore bodies to provide stability of stope exposures. When mining a mine block, stoping is suggested to be fulfilled gradually from the footwall to the hanging wall of the ore body by room-and-pillar methods leaving a dirt or ore inclusion in the block. This enables decrease in concentrating tension and compression stresses in the middle part of the dirt or ore inclusion resulting in its $1.5-2.0$ times greater stability. There is also determined that the stope stability is impacted by the horizontal thickness of the inclusion, the hardness ratio and the order of stoping in a mine block. Application of open stope methods in selective mining of complex structured ore bodies of Kryvyi Rih iron ore basin enables increased quality of the mined ore mass without significant capital and operating costs and results in better environment of the region.
\end{abstract}

\section{Introduction}

Kryvyi Rih iron ore basin is represented by thick deposits of rich 
and lean ores with dirt or ore inclusions (DOI) of 2 to $15 \mathrm{~m}$ [1-3]. The Protodiakonov hardness ratio of DOI is $8-6$, that is on average by 4-6 units higher than that of the main massif. DOI in rich ores make nearly $300 \mathrm{mln} t$ of which up to 800 thousand t are mined annually [4-6].

Underground mining of complex structured ore bodies (CSOB) is conducted by bulk-caving and open stope methods resulting in 3-6\% less iron content in the mined ore and 1.2-1.5 times greater than standard ore losses. Thus, the amount of the mined ore with the iron content of over $62 \%$ does not exceed $60 \%$ that leads to loss of the world sales market.

To increase sales, mining enterprises apply resource-saving technologies enabling increase of volumes of mined ore with the iron content of $60 \%$ to $80 \%$. This is achieved through use of a complex approach considering the concept of the environmental-economic system management and taking into account availability of functioning elements applying the organizational-technical control theory. The results of studying ore raw material mining and processing enable concluding that concentration efficiency indicators depend greatly on operational information and current technological processes. In most cases, when developing nondestructive control methods, electromagnetic, ultrasonic and radiometric techniques are used. However, all these approaches result in not only greater mining costs but also deterioration of the regional environment [7-10].

To increase mining of non-diluted ore at Kiruna mine (Sweden), selective mining with sorting ore mass underground and its transporting by main shafts is used. To support main openings, the mine applies modern methods of controlling the state of the rock massif disturbed by underground mining. It should be noted that their implementation at Kryvbas underground mines will lead to deterioration of labour conditions and increased mining costs due to complicated mining, geological and technical conditions [11-15].

Development of complex structured deposits is highlighted in many investigations dealing with determining regulations of extraction indicators, manifestations of rock pressure, sequence of mining and determining parameters of basic constructive elements of mining systems [16-18]. Efficiency of mining CSOB is proved to be impacted by mining geological and technical conditions, as well as by the order of stoping, rock pressure, mining intensity, number and stability 
of pillars, level height, mutual arrangement of main strike stopes and pillars.

When applying room-and-pillar methods, the iron content in the mined ore mass increases as compared with bulk caving systems but conditions of further mining deteriorate due to changes in rock massif stresses caused by concurrent appearance of tension and compression stresses [19-21].

Methods. According to [22-24], to provide stability of stopes considering changes of stress concentration, it is practicable to apply open stope methods taking into account physical and mechanical properties of DOI and sequence of mining a block.

To settle the problem of iron content increase and ore loss decrease when mining deposits represented by complex structured ore bodies, it is reasonable to apply the method suggested in [25-28]. The authors suggest modernization of traditional concentrating through hydrometallurgical and chemical processing that enhances efficiency of concentration for the account of using other energy kinds. This direction of modernization is based on processes of force impacts on a substance during disintegration in the activator and does not consider processes connected with mining useful minerals by underground methods.

The critical analysis of works dealing with mining and processing useful minerals enables the following conclusions:

1. Most authors suggest increase of the iron content in the mined ore at the expense of building an underground or surface mining and concentrating complex that will result in increased mining costs and lost world markets.

2. Increase of the iron ore content in the mined ore at the first stage may be achieved through applying resource-saving selective mining aimed at excluding the concentration process. At that, mining of ore bodies with horizontal thickness of dirt or ore inclusions of less than $12 \mathrm{~m}$ is suggested to be conducted by the traditional underground method involving concentrating combines.

Research tasks. Thus, when mining CSOB, the necessity arises to enhance the resource-saving technology which provides the iron content increase at selective mining of deposits depending on mining systems applied. That is why, it is essential to determine impacts of dirt inclusion thickness and a mining system on the mined ore mass vol- 
Stage I

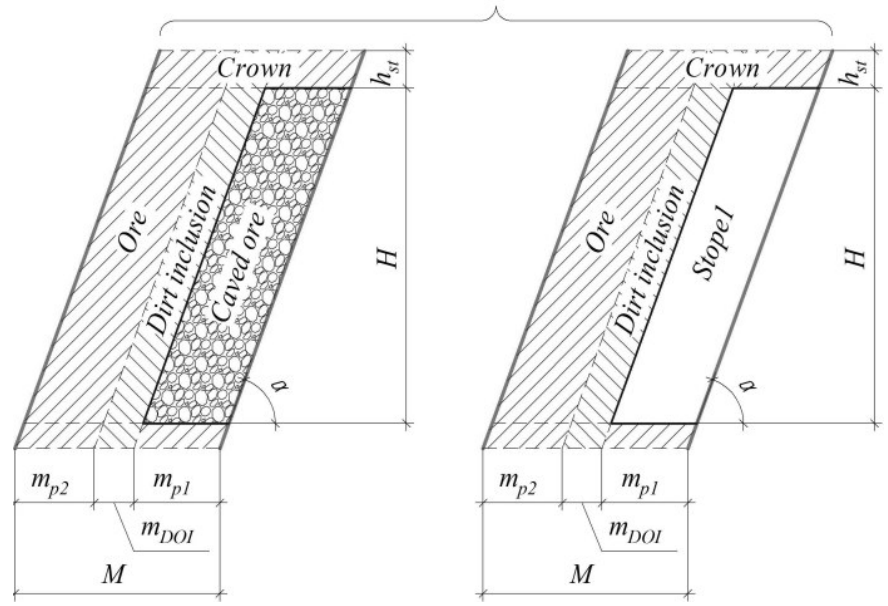

Stage II
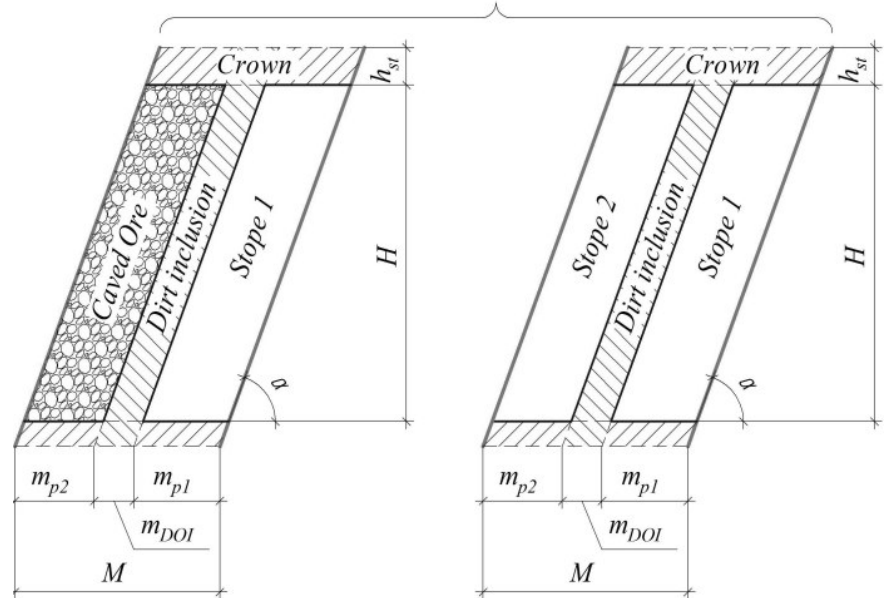

Fig. 1. The basic diagram of mining complex structured ore bodies in stable ores by open stope systems

Mining a block represented by CSOB from the footwall to the hanging wall changes the character of stresses and, consequently, produces a significant impact on DOI stability, Fig. 2. 


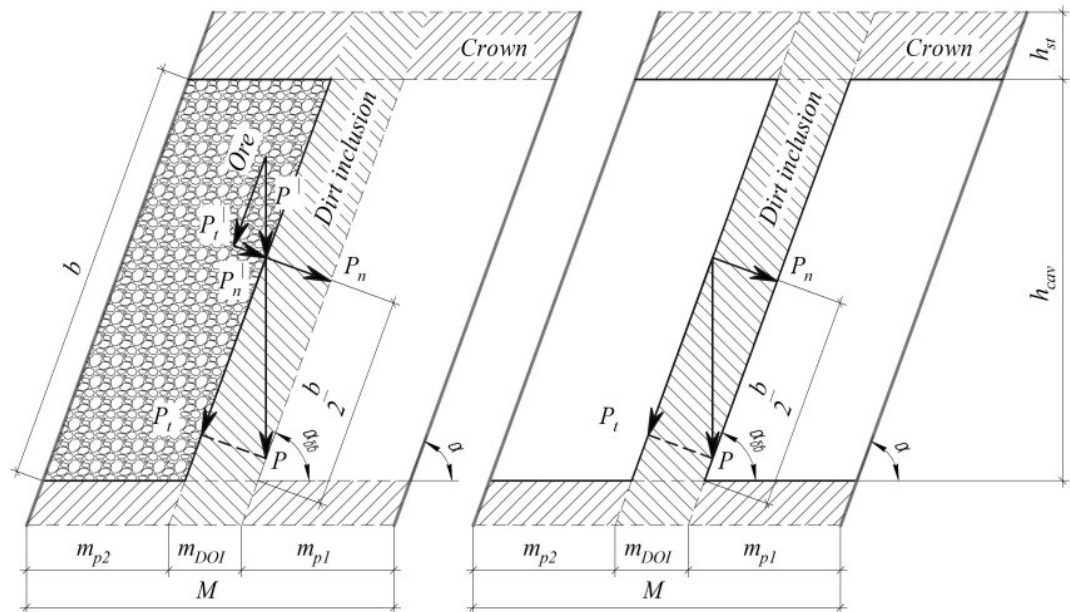

Fig. 2. The computational diagram for determining constructive elements of the room-and-pillar mining method when mining a stope according to option 2

Thus, at stage I after the exposure at the footwall is created (stope 1 ), on the contour of DOI there occur tension stresses. After breaking the ore massif and its further drawing from stope 2 (see Fig. 1), the tension stresses on the contour of DOI with stope 1 decrease and there appear compression stresses on the other side of DOI.

Maximum tension stresses on the contour of DOI and stope 1 will appear after stope 2 caving. That is why, when determining the permissible length of the exposure, it is essential to take into account weight of the caved rocks that will impact tensile stresses on the DOI - stope 1 contour. Fig. 3 demonstrates that DOI is impacted by the caved ore in the footwall triangle.

Maximum stresses occurring in the pillar presented as sandwiched beam impacted by the caved ore weight are calculated by the expression $[5,29]$

$$
\sigma_{\text {max }}=\frac{6 \cdot\left(M_{x}+M_{r}\right)}{l_{D O I} \cdot m_{D O I}^{2}},
$$

where $\sigma_{x}$ is maximum stresses, $\mathrm{t} / \mathrm{m} ; M_{x}$ is the maximum bending moment value at part $z$ of the DOI exposure length along the axis $x, \mathrm{t} / \mathrm{m}$; $M_{r}$ is the maximum bending moment caused by caved rocks, $\mathrm{t} / \mathrm{m} ; l_{D O I}$ 
is the maximum permissible length of the dirt or ore inclusion exposure, $\mathrm{m} ; m_{D O I}$ is normal thickness of the dirt or ore inclusion, $\mathrm{m}$.

The maximum bending moment of the triangular shape caused by caved rocks is calculated by the formula

$$
M_{r}=A \cdot z+M_{a}-\frac{q_{r} \cdot z^{2}}{6}=\frac{3 \cdot q_{r} \cdot l_{r}}{20} \cdot \frac{l_{r}}{2}-\frac{q_{r} \cdot l_{r}^{2}}{30}-\frac{q_{r} \cdot l_{r}^{2}}{24},
$$

where $q_{r}$ is weight of the caved ore in the triangle of the footwall per $1 \mathrm{~m}$ of DOI length, $\mathrm{t} / \mathrm{m}^{2} ; l_{r}$ is the inclined length of the caved rocks at the footwall, $\mathrm{m}$.

After formula (2) is simplified, the following expression for determining the maximum bending moment is obtained

$$
M_{r}=\frac{2 \cdot q_{r} \cdot l_{r}^{2}}{3} .
$$

Maximum stresses occurring in DOI and calculated according to formula (1) considering the maximum bending moment of the caved ore (3) are determined by the expression

$$
\sigma_{\max }=\frac{6\left(\frac{q \cdot l_{B O I}^{2}}{24}+\frac{2 \cdot q_{r} \cdot l_{r}^{2}}{3}\right)}{l_{D O I} \cdot m_{D O I}^{2}}=\frac{q \cdot l_{B O I}^{2}+16 \cdot q_{r} \cdot l_{r}^{2}}{4 \cdot l_{D O I} \cdot m_{D O I}^{2}} .
$$

It should be taken into account that the length of the dirt or ore inclusion equals the inclined length of the caved ore, so expression (4) will look like

$$
\sigma_{\text {max }}=\frac{q \cdot l_{D O I}+16 \cdot q_{r} \cdot l_{D O I}}{4 \cdot m_{D O I}^{2}} .
$$

The maximum permissible length of the DOI exposure presented as a beam considering the maximum bending moment of the caved ore weight is determined by the expression

$$
l_{B O I}=\frac{4 \cdot \sigma_{\max } \cdot m_{D O I}^{2}}{q+16 \cdot q_{r}}=\frac{4 \cdot K_{f} \cdot f \cdot K_{s t r . w} \cdot m_{D O I}^{2}}{\left(a_{I I} \cdot m_{D O I} \cdot \gamma_{D O I}+16 \cdot q_{r}\right) \cdot K_{s t}},
$$

where $K_{f}$ is the conversion rock hardness into stress ratio; $f$ is the hardness ratio of rocks of the dirt or ore inclusion (Protodyakonov scale); $K_{s t r . w}$ is the ratio of structural rock weakening caused by fractures (accepted from 0.65 to 0.95 ); $K_{s t}$ is the rock hardness ratio (ac- 
cepted 1.5-2.0).

The caved ore weight in the triangle of the footwall per $1 \mathrm{~m}$ of DOI length

$$
q_{r}=\frac{h_{s t} \cdot B \cdot \gamma_{o}}{2 \cdot K_{r}}=\frac{h_{s t}^{2} \cdot \gamma_{o} \cdot \operatorname{tg} \alpha}{2 \cdot K_{r}}=\frac{h_{s t} \cdot \gamma_{o} \cdot \sin ^{2} \alpha}{2 \cdot K_{r} \cdot \cos \alpha},
$$

where $h_{s t}$ is the height of the caved ore layer (height of a level or sublevel), m; $\varepsilon$ is the caved ore width in the upper part of the stope of stage II of mining, $\mathrm{m} ; \gamma_{\mathrm{o}}$ is the volume weight of ore, $\mathrm{t} / \mathrm{m}^{3} ; K_{r}$ is the primary ore loosening factor; $\alpha$ is the dirt or ore inclusion dip angle, degrees.

On inserting (7) into (8) we obtain

$$
l_{D O I}=\frac{4 \cdot m_{D O I}^{2} \cdot K_{f} \cdot f \cdot K \cdot K_{r} \cdot \cos \alpha}{\left(a_{I I} \cdot m_{D O I} \cdot \gamma_{D O I} \cdot K_{r} \cdot \cos \alpha+8 \cdot h_{s t} \cdot \gamma_{O} \cdot \sin ^{2} \alpha\right) \cdot K_{S t}} .
$$

The results of the calculations enable building dependencies of the exposure span of the dirt or ore inclusion (Fig. 3) and width of the stope of stage II of mining.

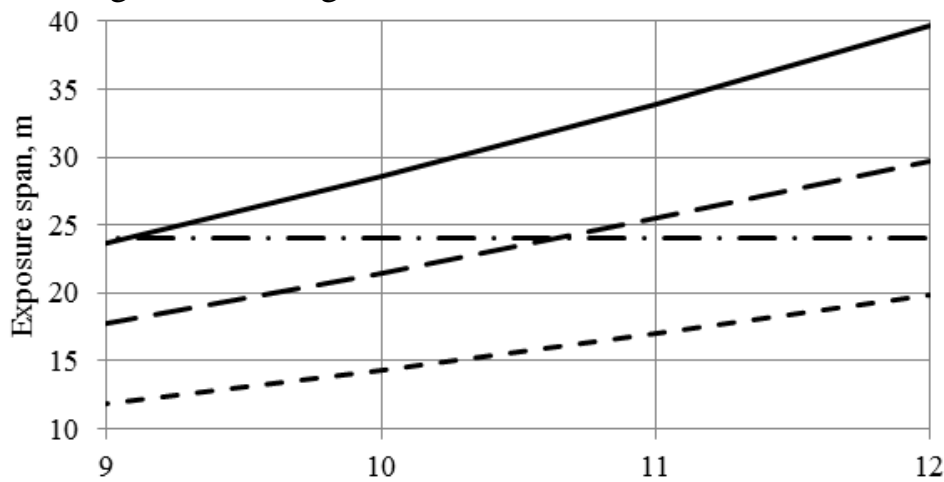

Normal thickness of dirt or ore inclusion, $\mathrm{m}$

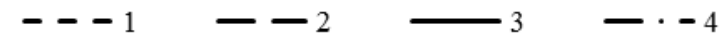

Fig. 3. Dependencies if the maximum inclusion length on the normal DOI thickness and hardness at the width of the stage II stope of $25 \mathrm{~m}$ (option 2): 1-5 is the at DOI hardness of respectively $8,12,16$; 6 is the permissible length (according to ROMI)

The dependencies in Fig. 3 demonstrate that increase of thickness of DOI from 9 to $12 \mathrm{~m}$ with its hardness of 12 (Protodiakonov scale) causes increase of the exposure length from 12 to $40 \mathrm{~m}$. It should be 
noted that, according to the technique developed by the Research Ore Mining Institute (ROMI), the maximum stable length of an exposure for given design conditions should not exceed $24 \mathrm{~m}$. thus, according to the calculations performed, if a stope is created with the exposure span of $24 \mathrm{~m}$ and with DOI hardness of 8 , it will be destroyed regardless of the inclusion thickness.

The diagrams in Fig. 4 demonstrate that increase of the width of the stope along the strike from 25 to $60 \mathrm{~m}$ at normal thickness of the dirt or ore inclusion of $10 \mathrm{~m}$ decreases the maximum span of the exposure from 36 to $15 \mathrm{~m}$ with the DOI decreased hardness from 16 to 8 .

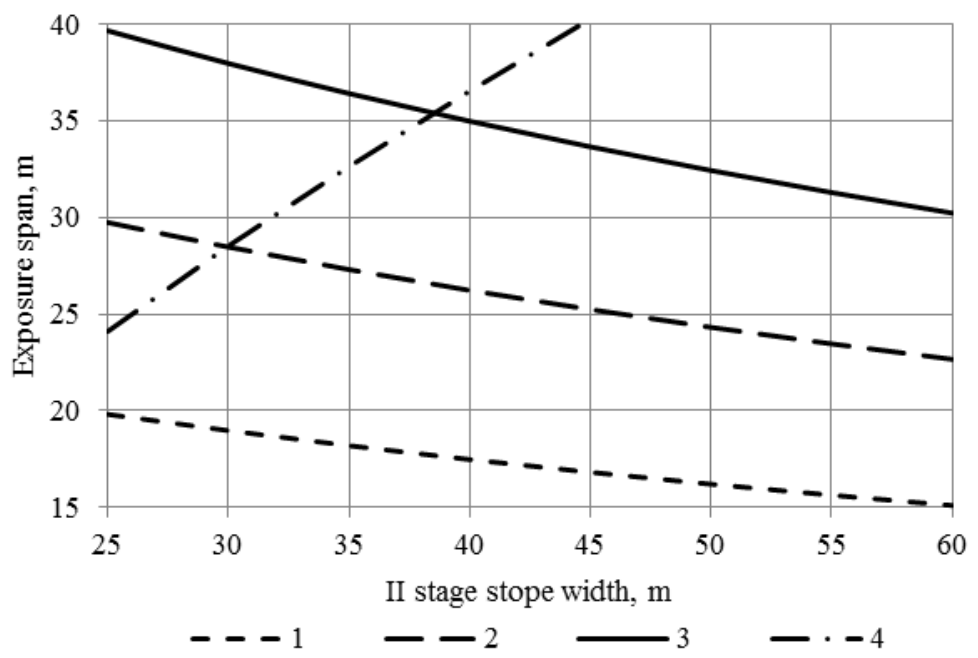

Fig. 4. Dependencies of the maximum inclusion length on the stope width and thickness of DOI rocks at the normal thickness of the dirt or ore inclusion of $10 \mathrm{~m}$ (option 2): 1-5 is the at DOI hardness of respectively 8, 10,12,14, 16; 6 is the permissible length (according to ROMI)

ANSIS-16.0 - based mathematical model of the change of fields of equivalent stresses in the rock massif around stopes at different stages of mining operations when mining the deposit from the footwall to the hanging wall is given in Fig. 5: initial - without mining operations; intermediate - formation of a stope in the footwall; final - formation of a stope in the hanging wall. 

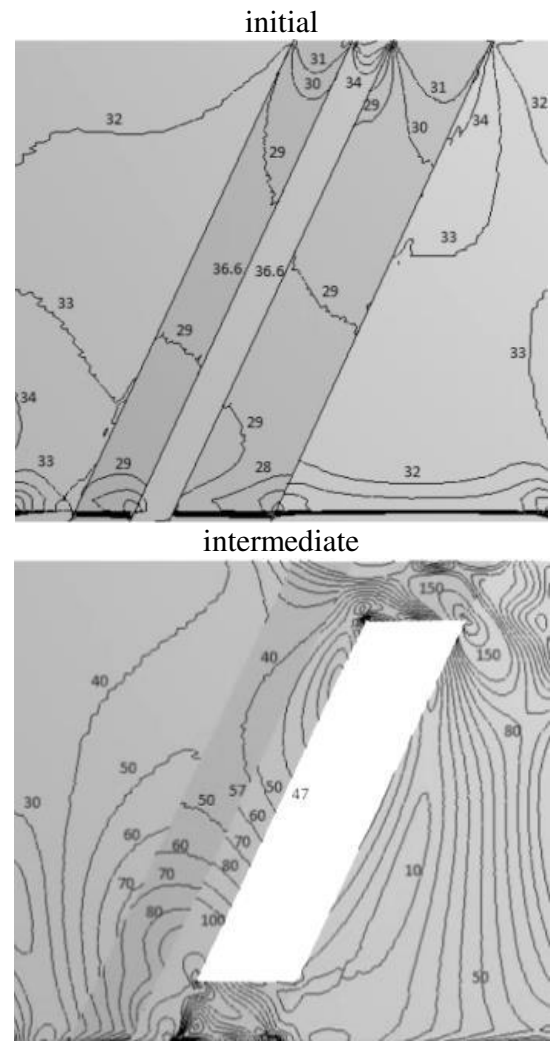

final

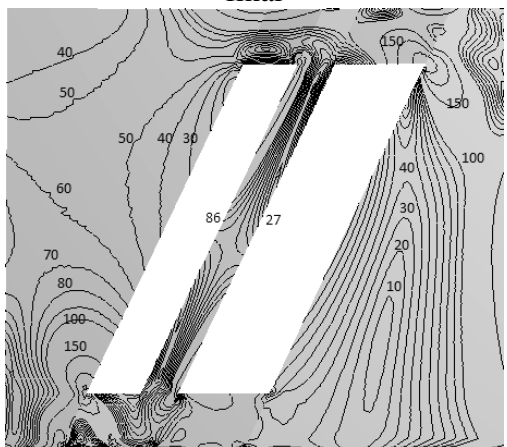

Fig. 5. The results of mining CSOB from the hanging wall at the compressive strength of the dirt inclusion of $160 \mathrm{MPa}$

Model studies registered a field of equivalent stresses in the massif 
around stopes and in the middle of the dirt inclusion at different stages of mining operations (Fig. 1, option 2). There were conducted 9 series of studies that differed from each other by physical and mechanical properties of the rock massif and DOI, other parameters (mining depth, level height, thickness) remained unchanged. The results of the studies enable building dependencies of changes of equivalent stresses in the middle part of the dirt inclusion, Fig. 6.

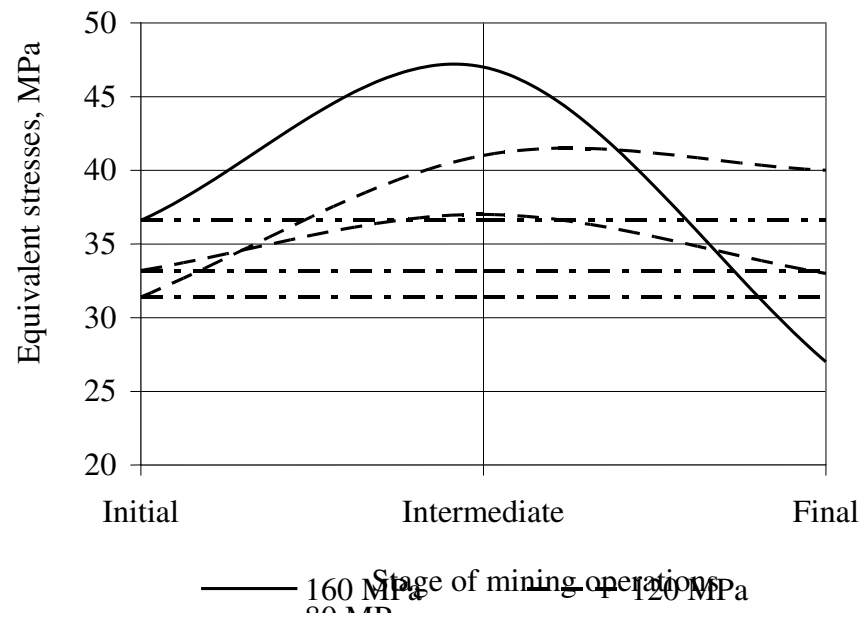

Fig. 6. Dependencies of equivalent stresses changes in the middle part of the dirt inclusion on the stage of mining operations, ultimate strength of DOI rock at ultimate strength of ore of $90 \mathrm{MPa}$ and the level height of $90 \mathrm{~m}$

The diagrams in Fig. 6 show that the character of equivalent stresses changes in DOI in its middle part is only impacted by the order of mining operations in a mine block. At that, further loading beyond the yield point increases the proportional limit according to Hooke's law [4, 5].

Thus, when the compressive strength is greater than $120 \mathrm{MPa}$ (rock hardness of 12, Protodiakonov scale), the I and II stage stopes will be stable. It should be noted that mathematical modeling cannot practically reproduce the rock massif and that is why the stope exposure length should be decreased by the stability safety factor. 


\section{Conclusions}

According to the study results, selective mining of complex structured ore bodies enables increasing the iron content in the mined ore mass. However, high indicators of mining can be achieved when applying certain mining systems in current mining and geological conditions. Ore bodies containing dirt inclusions of 4 to $12 \mathrm{~m}$ thick should be mined by mining systems used at underground mines of Kryvyi Rih basin.

Modeling results enable determining that at the level heights of 90 $\mathrm{m}$ (the span of the inclined exposure of $58.9 \mathrm{~m}$ ) and the stope width of $25 \mathrm{~m}$ at DOI ultimate strength less than $120 \mathrm{MPa}$ the exposure remains stable. When the ultimate strength exceeds $120 \mathrm{MPa}$, the exposure span will be instable, DOI and stopes will be destroyed.

Thus, application of selective mining methods when mining stopes presented by CSOB will enable not only enhancing mined ore mass volumes and, consequently, retaining the world market but also decreasing mining and processing costs.

References

1. Stupnik, M.I., Kalinichenko, V.O., Kalinichenko, O.V., Muzika, I.O., Fed'ko, M.B., \& Pismennyi, S.V. (2015). The research of strain-stress state of magnetite quartzite deposit massif in the condition of mine "Gigant-Gliboka" of central iron ore enrichment works (CGOK). Metallurgical and mining industry, (7), 377-383.

2. Stupnik, M.I., Kalinichenko, V.O., Pysmennyi, S.V., \& Kalinichenko, O.V. (2018). Determining the qualitative composition of the equivalent material for simulation of Kryvyi Rih iron ore basin rocks. Naukovyi Visnyk Natsionalnoho Hirnychoho Universytetu, (4), 21-27. https://doi.org/10.29202/nvngu/2018-4/4

3. Khomenko, O., \& Rudakov, D. (2010). The first Ukrainian corporative university. New Techniques and Technologies in Mining - Proceedings of the School of Underground Mining, 203-206. https://doi.org/10.1201/b11329-34

4. Stupnik, N., Kalinichenko, V., \& Pismennyi, S. (2013). Pillars sizing at magnetite quartzites room-work. Annual Scientific-Technical Collection - Mining of Mineral Deposits, 11-15. http://dx.doi.org/10.1201/b16354-4

5. Pysmennyi, S., Brovko, D., Shwager,N., Kasatkina, I., Paraniuk, D., \& Serdiuk, O. (2018). Development of complexstructure ore deposits by means of chamber systems under conditions of the Kryvyi Rih iron ore field. Eastern-European Journal of Enterprise Technologies, 5(1(95)), 33-45.

6. Stupnik, N., Kalinichenko, V., Pismennij, S., \& Kalinichenko, E. (2015). Features of underlying levels opening at "ArsellorMittal Kryvyic Rih" underground mine. New Developments in Mining Engineering 2015: Theoretical and Practical Solutions of Mineral Resources Mining, 39-44. https://doi.org/10.1201/b19901-8

7. Morkun, V., Morkun, N., \& Pikilnyak, A. (2015). The study of volume ul- 
trasonic waves propagation in the gas-containing iron ore pulp. Ultrasonics, (56), 340-343.

8. Morkun, V., Morkun, N., \& Pikilnyak, A. (2014). Ultrasonic facilities for the ground materials characteristics control. Metallurgical and Mining Industry, (2), 31-35.

9. Morkun, V., Morkun, N., \& Pikilnyak, A. (2014) Simulation of high-energy ultrasound propagation in heterogeneous medium using k-space method. Metallurgical and Mining Industry, (3), 23-27.

10. Morkun, V., Morkun, N., \& Pikilnyak, A. (2014) Ultrasonic phased array parameters determination for the gas bubble size distribution control formation in the iron ore flotation. Metallurgical and Mining Industry, (3), 28-31.

11. Dineva, S., \& Boskovic, M. (2017). Evolution of seismicity at Kiruna Mine. In Proceedings of the Eighth International Conference on Deep and High Stress Mining (pp. 125-139). Perth, Australia: Australian Centre for Geomechanics.

12. Biruk, Y., \& Mwagalanyi, Hannington. (2010). Investigation of Rock-fall and Support Damage Induced by Seismic Motion at Kiirunavaara Mine. Department of Civil, Environmental and Natural Resources Engineering.

13. Lozynskyi, V., Saik, P., Petlovanyi, M., Sai, K., \& Malanchuk, Z. (2018). Analytical Research of the Stress-Deformed State in the Rock Massif around Faulting. International Journal of Engineering Research in Africa, (35), 77-88.

14. Dychkovskyi, R.O., Lozynskyi, V.H., Saik, P.B., Petlovanyi, M.V., Malanchuk, Y.Z., \& Malanchuk, Z.R. (2018). Modeling of the disjunctive geological fault influence on the exploitation wells stability during underground coal gasification. Archives of Civil and Mechanical Engineering, 18(4), 1183-1197.

15. Vladyko, O., Kononenko, M., \& Khomenko, O. (2012). Imitating modeling stability of mine workings. Geomechanical Processes During Underground Mining Proceedings of the School of Underground Mining, 147-150.

16. Fedko, M.B., Kolosov, V.A., Pismennyy, S.V., \& Kalinichenko, Ye.A. (2014). Ekonomicheskiye aspekty perekhoda na bestrotilovyye vzryvchatyye veshchestva pri podzemnoy dobyche rud v Krivorozhskom basseyne. Naukovyi Visnyk Natsionalnoho Hirnychoho Universytetu, (4), 79-84.

17. Stupnik, N., Kalinichenko,V., Kolosov, V., Pismennyi, S., \& Shepel, A. (2014). Modeling of stopes in soft ores during ore mining. Metallurgical and mining industry, (3), 32-36.

18. Stupnik, N.I., Kalinichenko, V.A., Kolosov, V.A., Pismenniy S.V., \& Fedko M.B. (2014). Testing complex-structural magnetite quartzite deposits chamber system design theme. Metallurgical and mining industry, (2), 89-93.

19. Stupnik, M., Kolosov, V., Kalinichenko, V., \& Pismennyi, S. (2014). Physical modeling of waste inclusions stability during mining of complex structured deposits. Progressive Technologies of Coal, Coalbed Methane, and Ores Mining, 25-30. https://doi.org/10.1201/b17547-6

20. Stupnik, N.I., Fedko, M.B., Kolosov, V.A., \& Pismennyy S.V. (2014). 
Razrabotka rekomendatsiy po vyboru tipa krepleniya gornykh vyrabotok i sopryazheniy v uslovii uranovykh shakht GP "VOSTGOK". Naukovyi Visnyk Natsionalnoho Hirnychoho Universytetu, (5), 21-25.

21. Kalinichenko, V., Pysmennyi, S., Shvaher, N., Kalinichenko, O. (2018). Selective underground mining of complex structured ore bodies of Kryvyi Rih Iron Ore Basin. E3S Web of Conferences, (60), 00041. https://doi.org/10.1051/e3sconf/20186000041

22. Kononenko, M., \& Khomenko, O. (2010). Technology of support of workings near to extraction chambers. New Techniques and Technologies in Mining Proceedings of the School of Underground Mining, 193-197.

23. Khomenko, O., Kononenko, M., \& Petlovanyi, M. (2015). Analytical modeling of the backfill massif deformations around the chamber with mining depth increase. New Developments in Mining Engineering 2015: Theoretical and Practical Solutions of Mineral Resources Mining, 265-269. https://doi.org/10.1201/b19901-47

24. Khomenko, O., Kononenko, M., \& Danylchenko, M. (2016). Modeling of bearing massif condition during chamber mining of ore deposits. Mining of Mineral Deposits, 10(2), 40-47. https://doi.org/10.15407/mining10.02.040

25. Carusone, O., \& Hudyma, M. (2017). Variations in apparent stress and energy index as indicators of stress and yielding around excavations. In Proceedings of the First International Conference on Underground Mining Technology. Australian Centre for Geomechanics, 205-218.

26. Tarasyutin, V.M. (2015). Geotechnology features of high quality martite ore from deep mines of Kryvyi Rih basin. Naukovyi Visnyk Natsionalnoho Hirnychoho Universytetu, (1), 54-60.

27. Lutsenko, I., Fomovskaya, E., Koval, S., \& Serdiuk, O. (2017). Development of the method of quasioptimal robust control for periodic operational processes. Eastern-European Journal of Enterprise Technologies, 4(2(88)), 52-60.

28. Plevako, V., Potapov,V., Kycenko, V., Lebedynecj I., \& Pedorych, I. (2016). Analytical study of the bending of isotropic plates, inhomogeneous in thickness. Eastern-European Journal of Enterprise Technologies, 4(7(82)), 10-16.

29. Tsarikovskiy, V.V. Sakovich, V.V., \& Nedzvetskiy, A.V. (1987). Opredelenie i kontrol' dopustimykh razmerov konstruktivnykh elementov sistem razrabotki na rudnikakh Krivbassa. Krivoy Rog, Nauchno-issledovatel'skiy gornorudnyy institut.

30. Lavrinenko, V.F., \& Lysak, V.I. (1991). Uroven' udaroopasnosti porod na glubokikh gorizontakh shakht Krivbassa. Razrabotka rudnykh mestorozhdeniy, (52), 30-37. 